\title{
To Evaluate Different Soft Tissue Liners, as Functional Impression Materials, by Determining its Effect on Surface Roughness of Dental Stone Over a Time Period: An In-Vitro Study
}

\author{
Swapnil B Shankargouda ${ }^{1 *}$, Preena.Sidhu ${ }^{2}$ and Sounyala.N.Rayannavar ${ }^{3}$ \\ ${ }^{1}$ Department of Prosthodontics and Crown and Bridge, Kle academy of Higher Education and Research's VK institute of Dental Sciences, India
} ${ }^{2}$ MDS, Conservative Dentistry and Endodontics Faculty of Dentistry, SEGi University, Kota Damansara, Malaysia

${ }^{3}$ MDS, Prosthodontics and Crown and Bridge Reader, KLE Academy of Higher Education and Research's VK Institute of Dental Sciences, Belgaum, India

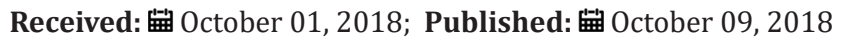

*Corresponding author: Swapnil B Shankargouda, Senior Lecturer, Department of Prosthodontics and Crown and Bridge, Kle Academy of Higher Education and Research's VK institute of Dental Sciences, Nehru Nagar, JNMC Campus, India

\section{Abstract}

a) Purpose: To evaluate, compare and contrast the changes in surface roughness of dental stone casts, recovered from commercially available chair-side soft liners, used as functional impression materials.

b) Methods: Ten disk-shaped denture soft liner samples [18 $\mathrm{mm}$ wide $\times 2 \mathrm{~mm}$ thick] were fabricated and dental stone poured over it after zero hours [control], one day, seven days, fourteen days and twenty one days, with a total sample size of 100 obtained from GC SOFT LINER [50 samples] and MOLLOSIL [50 samples] respectively.The dental stone samples were then evaluated for mean surface roughness values [Ra] using a profilometer.

c) Results: Student's paired t test $[\mathrm{p}<0.05]$ and Co-efficient of variance [C.V] test was used for statistical analysis. The mean surface roughness values of MOLLOSIL samples increased gradually and consistently over the period of zero hours to twenty-one days in comparison to the GC SOFT LINER samples.

d) Conclusion: Within the limitations of this study, silicone-based soft tissue liner showed better results than the acrylic-based soft liner in terms of surface roughness, over the period of zero hours to twenty-one days.

\section{Introduction}

Acrylic resin denture base material forms an interface of the oral mucosa which bears the occlusal forces and acts as an artificial foundation and maintains the artificial teeth in place. The modulus of elasticity [stiffness] of the tissues on which they rest [1.25$5.0 \mathrm{Mpa}$ ] is significantly lower compared to the acrylic denture base material [2400Mpa] [1-3]. To prevent the likelihood of discomfort of denture base material due to tissue trauma and sore spots of the oral mucosa as a result of the friable nature of the supporting mucosa, areas of force concentration, or misfit of the denture base, soft liners covering the soft tissues was developed [4]. A soft denture liner is a polymeric material placed on the intaglio surface of the denture base to assimilate the forces produced by mastication and to act as a type of "shock absorber" between the occluding surfaces of a denture and the underlying oral mucosa [5]. Two main types of soft liners can be identified, namely plasticized acrylics and silicone elastomers, available in both, auto polymerized and heat- polymerized forms [6,7]. However, the International Organization for Standardization [ISO] classifies soft liner materials into two main types: ISO 10139-1:1991, Part 1: short-term materials and ISO 10139-2:1999, Part 2: materials for long-term use [8,9] Functional impression materials are those materials that are applied to the intaglio [basal] surface of an impression tray or a denture, that record the basal seat and border tissues position and topography in a functional position[10,11]. The placement of soft-liner material can be used as the final impression either following the initial set of material [as with other final impression materials] or by having the patient wear and function with the prosthesis for a defined period of time. However, there is no substantial data for the use of soft liners as functional impression material during denture fabrication $[12,13]$. During clinical use, denture with soft liner material comes in contact with some form of aqueous liquid solution namely saliva during function in oral cavity or water or denture cleansing agent during storage, thus making determination of water sorption and 
solubility of prime importance $[14,15]$. The usefulness of the soft liners as a soft lining material is limited depending upon the type of soft lining material, due to the leaching out of the plasticizer with consequent hardening of the material, thus resulting in the change of the physical and mechanical properties of the soft relining material with time in the patient's mouth [16-19]. However, surface roughness is considered an important factor in the adhesion and retention of microorganisms onto the surface, with an increased retention of microbial cells seen with an increase in surface roughness [20-25]. So, it is imperative to evaluate the changes in the surface roughness of the stone casts obtained from the soft tissue liners, when used as functional impression materials, over time, immersed in a liquid media. This study is an attempt to evaluate, compare and contrast two different commercially available soft tissue liners, used as functional impression materials, by determining its effect on surface roughness of dental stone over a time period.

\section{Materials and Methodology}

The materials and armamentarium used for the study are enumerated in Tables $1 \& 2$ accordingly. The methodology followed in this study involved, preparation of soft tissue liner samples, preparation of dental stone samples and surface roughness test of the dental stone samples [26,27].

Table 1: List of materials used for the study.

\begin{tabular}{|c|c|c|c|}
\hline S.No & Material & Manufacturer & $\begin{array}{c}\text { Recommended } \\
\text { ratio }\end{array}$ \\
\hline 1 & $\begin{array}{c}\text { Acrylic temporary } \\
\text { relining material }\end{array}$ & $\begin{array}{c}\text { GC-Fuji SOFT LINER, } \\
\text { GC India Inc }\end{array}$ & $\begin{array}{c}2.2 \mathrm{~g} / 1.8 \mathrm{~g} \\
\text { (Powder/Liquid) }\end{array}$ \\
\hline 2 & $\begin{array}{c}\text { Long term,chairside, } \\
\text { silicone soft liner }\end{array}$ & $\begin{array}{c}\text { MOLLOSIL,Detax } \\
\text { GmBh Co }\end{array}$ & $\begin{array}{c}1: 1(2-\text { paste } \\
\text { system) }\end{array}$ \\
\hline 3 & Type III dental stone & $\begin{array}{c}\text { KALSTONE,Kalabhai } \\
\text { Karson Pvt Ltd }\end{array}$ & $\begin{array}{c}30 \mathrm{ml} / 100 \mathrm{~g} \\
\text { (Water/Powder) }\end{array}$ \\
\hline 4 & Artificial saliva & $\begin{array}{c}\text { SALEVA,Goran Pvt } \\
\text { Ltd }\end{array}$ & - \\
\hline
\end{tabular}

Table 2: List of materials used for the study.

\begin{tabular}{|c|c|c|}
\hline S.No & Material & Manufacturer \\
\hline 1. & $\begin{array}{l}\text { Custom made metal mould (18mm } \\
\text { diameter, } 2 \mathrm{~mm} \text { thickness) with } 2 \\
\text { covering metal plates. }\end{array}$ & - \\
\hline 2. & Rubber bowl, plaster spatula, BP blade & - \\
\hline 3. & Long bladed mixing spatula & - \\
\hline 4. & Tweezer & - \\
\hline 5. & Mechanical vibrator & $\begin{array}{l}\text { major vibrator } \\
\text { c-71,Confident }\end{array}$ \\
\hline 6. & Mechanical vacuum mixer & $\begin{array}{l}\text { Cuumyx labo- } \\
14, \text { Confident }\end{array}$ \\
\hline 7. & Hydraulic press & Sirio \\
\hline 8. & Incubator & The ile co \\
\hline 9. & Profilometer & $\begin{array}{c}\text { SURFTEST SJ.201P/ } \\
\text { M,Mitutoyo }\end{array}$ \\
\hline
\end{tabular}

\section{Methodology Followed}

\section{a. Preparation of Soft Tissue Liner Discs}

A precise three plate metal mould was fabricated which can be separated and realigned one above the other accurately (Figure 1). The upper and lower metal plate consisted of flat plane metal which was used to maintain and acquire soft tissue liner discs of uniform thickness by application of opposing pressure over the middle metal plate. The middle metal plate consisted of 2 rows of 5 uniform discs with dimension, $18 \mathrm{~mm}$ wide and $2 \mathrm{~mm}$ deep [28]. The two soft tissue liners used for the study were mixed according to the manufacturer's recommendation at room temperature (Table 1). They were then carried and placed into the central plate containing the disc spaces and slightly overfilled. The three-plate metal mould assembly was centered, realigned and subjected to constant pressure on a hydraulic bench press for 15 minutes, in order to obtain soft tissue liner discs of uniform $2 \mathrm{~mm}$ thickness [29-32]. After 15 minutes, the upper plate was removed and the excess soft liner material was removed using a sharp blade to obtain 10 soft liner discs of uniform thickness and diameter (Figures 2 \& $3)$. Distorted, damaged or broken discs were discarded. Ten disc shaped specimens were recovered from the metal mould and then stored in artificial saliva in an incubator at $370 \mathrm{C}$ for zero hours [control], one day, seven days, fourteen days and twenty one days respectively. Thus, a total of 100 samples were prepared, with 50 soft tissue liner samples obtained from GC SOFT LINER and $50 \mathrm{soft}$ tissue liner samples from MOLLOSIL [33-35].
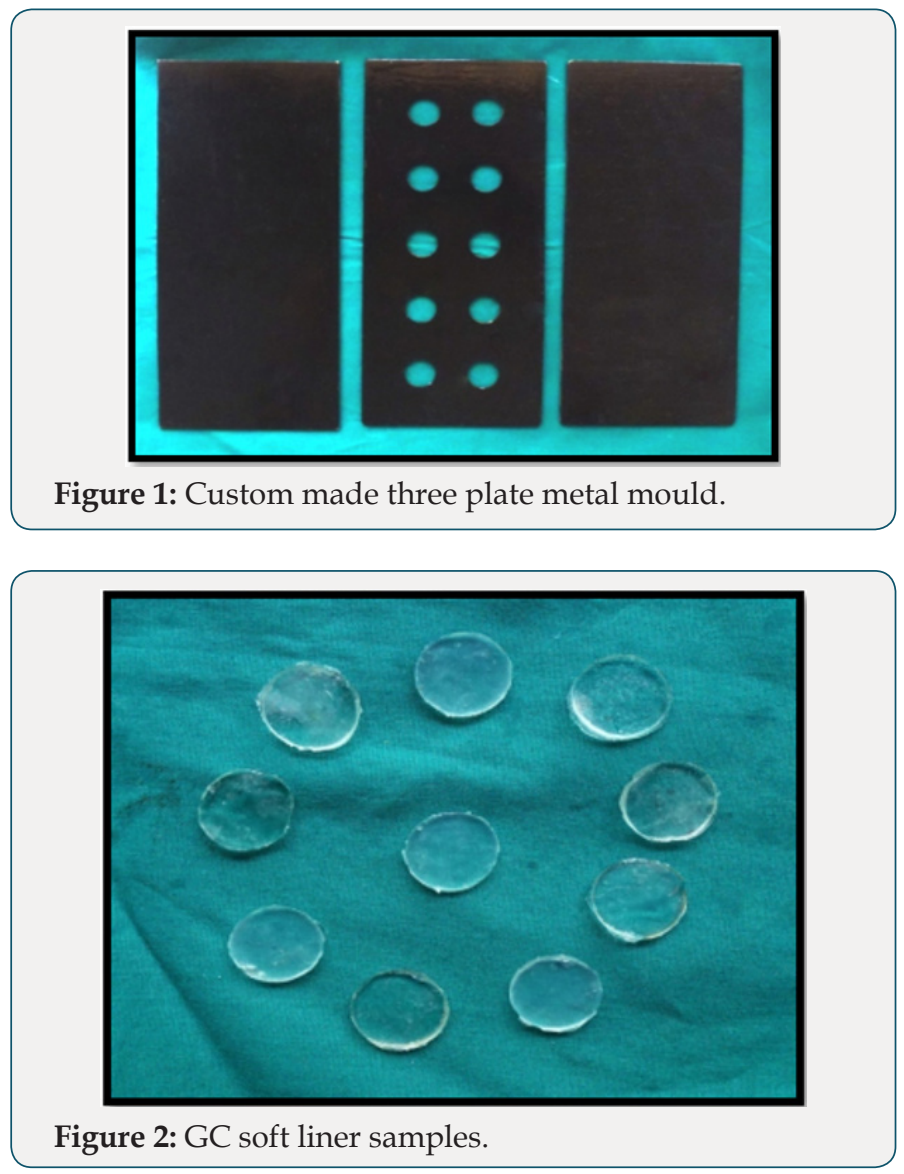


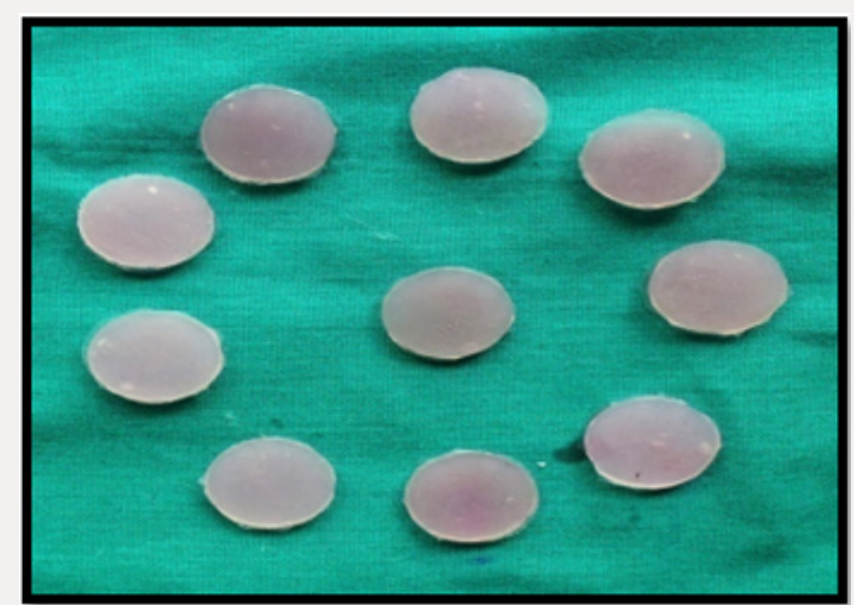

Figure 3: Mollosil Soft Tissue Liner Samples.

\section{b. Preparation of Dental Stone Samples}

Subsequent to time intervals, the dental stone was hand mixed with water in a rubber bowl and then under vacuum in an auto mixer for 15 seconds, using the manufacturer recommended water/powder ratio (Table 1). The mixed dental stone was poured over the soft-liner samples under gentle vibration and stored at room temperature for 60 minutes (Figures $4 \& 5$ ).

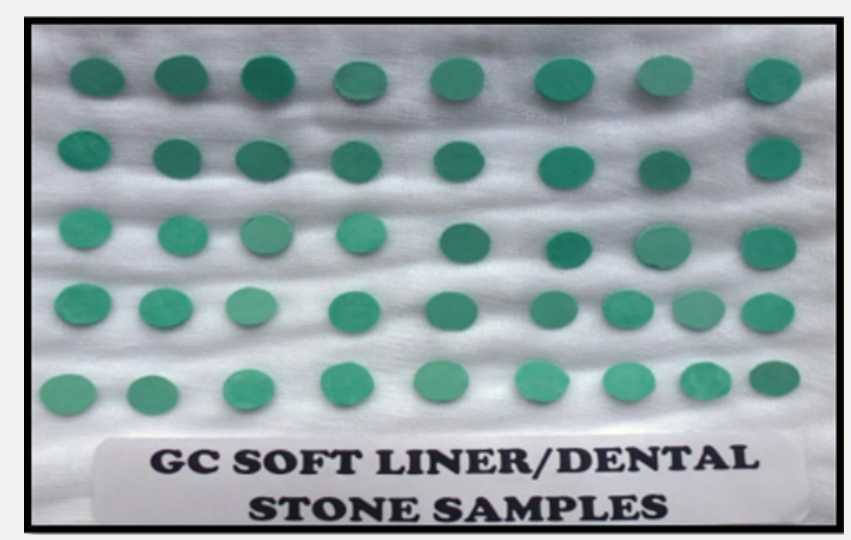

Figure 4: GC Soft Liner/Dental Stone Samples.

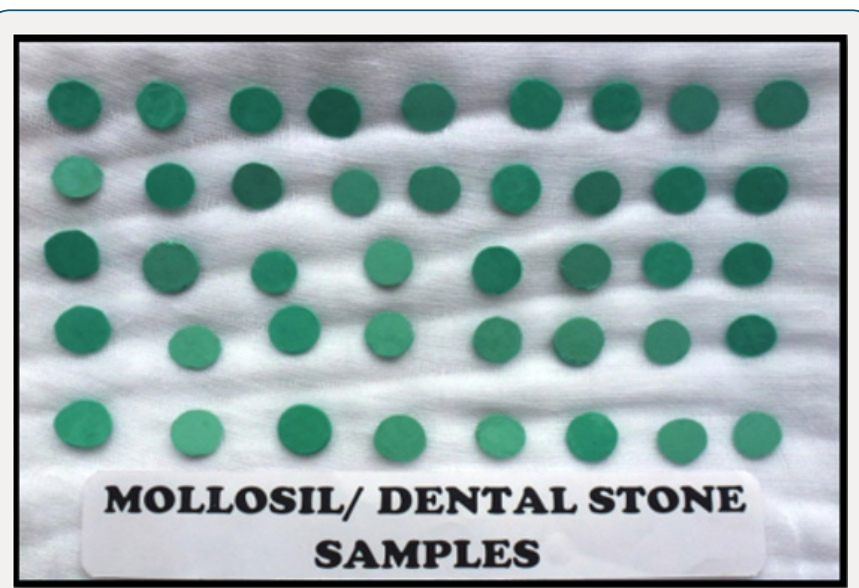

Figure 5: Mollosil/Dental Stone Samples.

\section{c. Surface Roughness Test of the Dental Stone Samples}

Subsequent to time intervals, the dental stone samples obtained from the soft tissue liner samples respectively, were tested for determining the surface roughness [Ra] values using a profilometer [36-38]. Ten disk-shaped specimens, for each soft tissue liner/stone sample combination were prepared after zero hours, one day, seven days, fourteen days and twenty-one days, with a total sample size of 100 obtained from GC SOFT LINER [50 samples] and MOLLOSIL [50 samples] respectively.

\section{d. Method of Statistical Analysis}

The data collected was tabulated in Microsoft Excel and statistically analysed using the SPSS [version 17] software. Student paired-t test $[\mathrm{p}<0.05]$ and Co-efficient of variance [C.V] tests were used to find a significant difference between two means [39].

\section{Results}

An in-vitro study was conducted in the Department of Prosthodontics including Crown and Bridge, Sri Siddhartha Dental College, Tumkuru, Karnataka, India to evaluate two different soft tissue liners, as functional impression materials, by determining its effect on surface roughness of dental stone over time [40-42].

Table 3: Surface roughness values $(\mu \mathrm{m})$ of dental stone samples obtained from GC soft liner samples recorded after five different time durations respectively.

\begin{tabular}{|c|c|c|c|c|c|c|c|c|c|c|}
\hline Sample duration & $\mathbf{1}$ & $\mathbf{2}$ & $\mathbf{3}$ & $\mathbf{4}$ & $\mathbf{5}$ & $\mathbf{6}$ & $\mathbf{7}$ & $\mathbf{8}$ & $\mathbf{9}$ & $\mathbf{1 0}$ \\
\hline Zero Hours (Control) & 0.88 & 0.87 & 0.89 & 0.88 & 0.86 & 0.87 & 0.9 & 0.86 & 0.88 & 0.89 \\
\hline One Day & 0.9 & 0.89 & 0.88 & 0.87 & 0.89 & 0.91 & 0.9 & 0.88 & 0.9 & 0.91 \\
\hline Seven Days & 0.89 & 0.9 & 0.9 & 0.87 & 0.89 & 0.92 & 0.88 & 0.89 & 0.91 & 0.9 \\
\hline Fourteen Days & 0.93 & 0.96 & 0.97 & 0.94 & 0.93 & 0.96 & 0.98 & 0.97 & 0.99 & 0.93 \\
\hline Twenty One Days & 1.02 & 1.04 & 1.05 & 0.99 & 1.02 & 0.99 & 1.03 & 1.04 & 1.02 & 0.98 \\
\hline
\end{tabular}

i. Data given in (Table 3) shows the surface roughness values [Ra] of dental stone samples recovered from GC SOFT LINER samples, recorded after five different time durations. ii. Data given in Table 4 shows the surface roughness values [Ra] of dental stone samples recovered from MOLLOSIL soft tissue liner samples, recorded after five different time durations respectively. 
Table 4: Surface roughness values $(\mu \mathrm{m})$ of dental stone samples obtained from Mollosil soft tissue liner samples recorded after five different time durations respectively.

\begin{tabular}{|c|c|c|c|c|c|c|c|c|c|c|}
\hline Sample duration & $\mathbf{1}$ & $\mathbf{2}$ & $\mathbf{3}$ & $\mathbf{4}$ & $\mathbf{5}$ & $\mathbf{6}$ & $\mathbf{7}$ & $\mathbf{8}$ & $\mathbf{9}$ & $\mathbf{1 0}$ \\
\hline Zero Hours(Control) & 0.88 & 0.86 & 0.87 & 0.85 & 0.86 & 0.88 & 0.86 & 0.85 & 0.87 & 0.88 \\
\hline One Day & 0.89 & 0.9 & 0.88 & 0.87 & 0.89 & 0.91 & 0.88 & 0.9 & 0.91 & 0.9 \\
\hline Seven Days & 0.89 & 0.9 & 0.9 & 0.89 & 0.87 & 0.92 & 0.9 & 0.91 & 0.89 & 0.88 \\
\hline Fourteen Days & 0.94 & 0.92 & 0.96 & 0.95 & 0.93 & 0.96 & 0.92 & 0.91 & 0.98 & 0.92 \\
\hline Twenty One Days & 0.94 & 0.98 & 0.95 & 0.99 & 1.02 & 0.96 & 0.96 & 1.01 & 1.02 & 0.99 \\
\hline
\end{tabular}

iii. Table 5 shows the comparison of the mean surface roughness values $[\mathrm{Ra}]$ of 10 dental stone samples obtained from GC SOFT LINER and MOLLOSIL soft tissue liner samples, consecutive to five different time durations namely zero hours [control], one day, seven days, fourteen days \& twenty one days.

Table 5: Comparison of mean surface roughness values (Ra) of GC soft liner/dental stone and Mollosil/dental stone samples against different time durations.

\begin{tabular}{|c|c|c|}
\hline \multirow{2}{*}{ Duration } & \multicolumn{2}{|c|}{ Mean } \\
\cline { 2 - 3 } & Gc Soft Liner & Mollosil \\
\hline Zero Hours (Control) & 0.88 & 0.87 \\
\hline One Day & 0.89 & 0.89 \\
\hline Seven Days & 0.89 & 0.9 \\
\hline Fourteen Days & 0.96 & 0.94 \\
\hline Twenty One Days & 1.02 & 0.98 \\
\hline
\end{tabular}

iv. Table 6 shows mean surface roughness values [Ra] of 10 dental stone samples obtained from GC SOFT LINER and MOLLOSIL soft tissue liners respectively at zero hours, which was taken as a control, to which other values were compared and evaluated statistically using co-efficient of variance [C.V]. The values obtained showed a slight \& statistically consistent amount of increase in the mean surface roughness values of GC SOFT LINER \& MOLLOSIL soft tissue liner samples up to seven days \& considerable amount of statistically inconsistent increase in mean surface roughness values of the two soft tissue liner samples was seen from seven days - twenty one days in comparison with the control group [zero hours].

Table 6: Comparison of co-efficient of variance (C.V) of GC soft liner and Mollosil samples for different time durations.

\begin{tabular}{|c|c|c|}
\hline \multirow{2}{*}{ Duration } & \multicolumn{2}{|c|}{ Co-Efficient Of Variance (C.V) } \\
\cline { 2 - 3 } & Gc Soft Liner & Mollosil \\
\hline Zero Hours (Control) & $1.43 \%$ & $1.36 \%$ \\
\hline One Day & $1.46 \%$ & $1.47 \%$ \\
\hline Seven Days & $1.61 \%$ & $1.61 \%$ \\
\hline Fourteen Days & $2.22 \%$ & $2.34 \%$ \\
\hline Twenty One Days & $2.23 \%$ & $2.82 \%$ \\
\hline
\end{tabular}

v. Table 7 shows the comparison of the mean surface roughness values [Ra] of GC SOFT LINER samples for different time durations to the control [zero hours] namely zero hours
- one day, zero hours- seven days, zero hours - fourteen days $\&$ zero hours-twenty one days, using Student's "paired-t" test $[\mathrm{p}<0.05$.

Table 7: Comparison of surface roughness (Ra) of GC soft liner/ dental stone samples for different time durations in relation to the control (ZERO hours) using paired t-test.

\begin{tabular}{|c|c|c|c|}
\hline T & Df & P-Value & $* \mathbf{P}<\mathbf{0 . 0 5}$ \\
\hline $\begin{array}{c}\text { Zero Hours (Control) - One } \\
\text { Day }\end{array}$ & -2.875 & 9 & $0.018^{*}$ \\
\hline $\begin{array}{c}\text { Zero Hours (Control) - Seven } \\
\text { Days }\end{array}$ & -2.547 & 9 & $0.031^{*}$ \\
\hline $\begin{array}{c}\text { Zero Hours (Control) - } \\
\text { Fourteen Days }\end{array}$ & -10.507 & 9 & $0.000^{*}$ \\
\hline $\begin{array}{c}\text { Zero Hours (Control) - Twenty } \\
\text { One Days }\end{array}$ & -15.652 & 9 & $0.000^{*}$ \\
\hline
\end{tabular}

vi. Table 8 shows the comparison of the mean surface roughness values [Ra] of MOLLOSIL soft tissue liner samples for different time durations to the control [zero hours] namely zero hours - one day, zero hours- seven days, zero hours - fourteen days \& zero hours-twenty one days, using Student's "paired-t" test $[\mathrm{p}<0.05]$.

Table 8: Comparison of surface roughness (Ra) of mollosil/ dental stone samples for different time durations in relation to the control (zero hours) using paired t-test.

\begin{tabular}{|c|c|c|c|}
\hline $\mathbf{T}$ & Df & P-Value & $* \mathbf{P}<\mathbf{0 . 0 5}$ \\
\hline $\begin{array}{c}\text { Zero Hours (Control) - One } \\
\text { Day }\end{array}$ & -6.384 & 9 & $0.000^{*}$ \\
\hline $\begin{array}{c}\text { Zero Hours (Control) - Seven } \\
\text { Days }\end{array}$ & -4.949 & 9 & $0.001^{*}$ \\
\hline $\begin{array}{c}\text { Zero Hours (Control) - } \\
\text { Fourteen Days }\end{array}$ & -10.673 & 9 & $0.000^{*}$ \\
\hline $\begin{array}{c}\text { Zero Hours (Control) - Twenty } \\
\text { One Days }\end{array}$ & -10.2 & 9 & $0.000^{*}$ \\
\hline
\end{tabular}

vii. The mean surface roughness values [Ra] of both the soft liner samples showed a statistically significant increase respectively.

viii. Table 9 shows the comparison of the percentage increase in surface roughness [Ra] of GC SOFT LINER and MOLLOSIL soft tissue liner samples for different time durations in relation to the control [zero hours] namely zero hours-one day, zero hoursseven days, zero hours - fourteen days and zero hours-twenty one days, using Student's "paired-t" test $[\mathrm{p}<0.05]$.The values 
obtained showed a slight percentage of increase in mean surface roughness values [Ra] of GC SOFT LINER \& MOLLOSIL soft tissue liner samples between zero hours-one day \& zero hoursseven days \& a considerable percentage of increase in mean surface roughness values [Ra] between zero hours-fourteen days \& zero hours-twenty one days. However, it showed a slight, consistent increase in the mean surface roughness values [Ra] of MOLLOSIL soft tissue liner samples between zero hourstwenty one days in comparison to the mean surface roughness values [Ra] of GC SOFT LINER soft tissue liner samples, which showed a considerable, inconsistent amount of increase.

Table 9: Comparison of percentage increase in surface roughness (Ra) of GC soft liner and Mollosil samples for different time durations in relation to the control (zero hours).

\begin{tabular}{|c|c|c|}
\hline \multirow{2}{*}{ Duration } & \multicolumn{2}{|c|}{ Percentage Increase (\%) } \\
\cline { 2 - 3 } & Gc Soft Liner & Mollosil \\
\hline $\begin{array}{c}\text { Zero Hours (Control) - } \\
\text { One Day }\end{array}$ & 1.7 & 2.7 \\
\hline $\begin{array}{c}\text { Zero Hours (Control) - } \\
\text { Seven Days }\end{array}$ & 1.9 & 3.44 \\
\hline $\begin{array}{c}\text { Zero Hours (Control) - } \\
\text { Fourteen Days }\end{array}$ & 8.8 & 8.42 \\
\hline $\begin{array}{c}\text { Zero Hours (Control) } \\
\text { - Twenty One Days }\end{array}$ & 15.9 & 13.4 \\
\hline Twenty One Days & $2.23 \%$ & $2.82 \%$ \\
\hline
\end{tabular}

ix. Table 10 shows the comparison of the percentage increase in mean surface roughness values [Ra] of GC SOFT LINER \& MOLLOSIL soft tissue liner samples with simultaneous increase in time durations namely zero hours to one day, one day to seven days, seven days to fourteen days $\&$ fourteen days to twenty-one days respectively.

Table 10: Comparison of percentage increase in surface roughness (Ra) of GC soft liner and Mollosil samples with simultaneous increase in time duration.

\begin{tabular}{|c|c|c|}
\hline \multirow{2}{*}{ Duration } & \multicolumn{2}{|c|}{ Percentage Increase (\%) } \\
\cline { 2 - 3 } & Gc Soft Liner & Mollosil \\
\hline $\begin{array}{c}\text { Zero Hours (Control)- } \\
\text { One Day }\end{array}$ & 1.7 & 2.7 \\
\hline One Day-Seven Days & 0.22 & 0.22 \\
\hline $\begin{array}{c}\text { Seven Days-Fourteen } \\
\text { Days }\end{array}$ & 6.8 & 4.9 \\
\hline $\begin{array}{c}\text { Fourteen Days-Twenty } \\
\text { One Days }\end{array}$ & 6.4 & 4.5 \\
\hline Twenty One Days & $2.23 \%$ & $2.82 \%$ \\
\hline
\end{tabular}

The values obtained showed a considerable amount of increase in mean surface roughness values of GC SOFT LINER samples from zero hours to twenty one days in comparison to MOLLOSIL samples, which showed a slight amount of increase in mean surface roughness values from zero hours to twenty one days. A considerable increase in the mean surface roughness values of MOLLOSIL samples was seen during the time duration of zero hours to one day, in comparison to the mean surface roughness value changes of GC SOFT LINER samples, however the mean surface roughness values were same after one day of immersion in artificial saliva for both the soft tissue liner samples [43-46].

\section{Discussion}

Soft liner materials are mainly divided into two types: auto polymerized [mouth cured] and heat-polymerized [processed] forms of plasticized acrylics and silicone elastomers [47].

\section{Mouth-Cured Soft Liners}

Three types of materials are generally used. The first two are acrylic based with the composition as follows:

a. Powder containing poly [ethyl methacrylate] and peroxide initiator, Liquid containing aromatic esters, ethanol, and tertiary amines.

b. Powder containing poly [ethyl methacrylate], ethyl glycolate as plasticizers and peroxide as initiator, Liquid containing methyl methacrylate and tertiary amines.

c. Addition silicone elastomers form the third group [4849].

\section{Processed Soft Liners}

The basic compositions of heat cured acrylic and silicone liners [heat and room temperature cured] are as follows:

\section{Heat Cured Acrylic Liner}

a) Polymer containing poly ethyl methacrylate or poly methyl methacrylate [50].

b) Monomer containing methyl methacrylate or n-Butyl methacrylate or ethyl methacrylate, at times ethyl acetate may be added.

c) Plasticizer containing butylpthalyl butyl glycolate [30\% to 59\%] or Di-n-butyl Phthalate [36.2\%] or 2-Ethylhexyl diphenyl phosphate [39\%].

\section{Silicone Liner}

a) Polymer containing $\alpha$ - $\omega$ - dihydroxy end-blocked poly dimethyl siloxane.

b) Cross-linking agent containing triethoxy silanol or ethyl polysilicate or methyltriacetoxy silane or acryloxyl silane [51].

c) Catalyst containing dibutylin dilaurate or stannous octoate or moisture or heat+benzoyl peroxide

d) Filler containing micro sized metal oxide or colloidal silica [16.5\% to $4.5 \%$ ].

However, the International Organization for Standardization [ISO] has standardized soft liner materials for removable dentures into two main types as ISO 10139-1:1991; Part 1: short-term use - used intraorally for up to 30 days \& ISO 10139-2:1999; Part 2: 
long-term use -one that maintains softness and elasticity for more than 30 days [52]. Soft lining materials are indispensable in modern removable prosthodontics and clinically they can be used for the following purposes.

A. To make functional impressions.

B. When placed in a denture against edentulous tissues, act as tissue conditioner to help tissue return to a healthy state.

C. To maintain the fit of the immediate dentures and prevent trauma to the underlying tissues following any oral surgical procedures.

D. For temporary assessment of border extensions.

E. SAUER JL enumerated some of the indications for use of soft liners. Residual alveolar ridges with bony undercuts and overlying thin non-resilient mucosa [53-54].

a) Knife edge mandibular ridges

b) Persistent denture sore mouth

c) Thin tissue relief overlying sharp median palatine suture and torus palatinus

d) In prosthodontic rehabilitation of congenital or acquired oral defects

e) Oral tissues subjected to radiation therapy.

For many years, the ideal protocol for returning the inflamed tissues overlying an edentulous ridge to a normal state, before making any impression has been to advise the patients to keep their dentures out of their mouth for a certain period of time [usually 48 hours].However, most of the patients do not conform to do this as they do not desire to be without their dentures for even a shorter duration of time. Tissue conditioners act as a viable alternative to return the oral tissues to a normal condition and act as functional impression materials for temporary denture relining accordingly. Placement of soft liner material can be used as the final impression either following the initial set of material [as with other final impression materials] or by having the patient wear and function with the prosthesis for a defined period of time. Functional impression materials are required to make an accurate replica of the surface topography of the underlying supporting tissues under functional and parafunctional loading, thus giving it a composite or modal form. The functional impression material should have adequate flow when loaded onto the denture to adapt the tissue adequately and should become rigid and elastic to prevent permanent distortion on removal from the mouth with adequate compatibility with the gypsum products [55-59]. However, it shows certain physical and microbiological disadvantages with surface colonization and infection by Candida albicans and other microorganisms resulting in denture stomatitis [60,61]. BILGE T. BAL, in 2008, conducted a pilot study among four soft liner materials [UFI-GEL, SOFTLINER, COE-SOFT \& VERTEX] and acrylic resin material to evaluate and compare the adhesive properties of oral micro flora onto their surfaces. It was concluded that soft liners showed greater adhesion of oral bacteria and Candida than the acrylic resin with soft liner materials showing the maximum number of micro-organisms. On the contrary, it is a proven fact that the continuous aspiration or swallowing of microorganisms from the dental plaque in immunocompromised patients or medicated elderly exposes them to further infection [62]. However, microbial adhesion to the appliance or prosthesis is influenced by the surface characteristics of the appliance namely surface roughness, surface free energy, surface tension, hydrophobicity etc. In 1988, KAZANJI MNM, WATKINSON AC tested for the absorption and solubility behaviour of five soft liners in distilled water and artificial saliva and concluded that all the tested soft liners except for Molloplast B [heat cured silicone rubber] showed lower absorption percentage and solubility in artificial saliva than distilled water. Thus, it was implied that when materials are tested, use of artificial saliva over distilled will show clinically relevant results. Among the surface properties of the materials used in denture construction that affect the adhesion of microorganisms, surface roughness provokes more adhesion of Candida and other microbial organism, which is of specific importance in denture-induced stomatitis pathogenesis. In accordance, VERRAN J \& MARYAN CJ concluded in their study that difference in surface topography influences the microbial attachment, more to a rougher surface than a smoother surface. Since 1960, various laboratory studies have been conducted to evaluate the physical properties of denture soft liners in accordance to its better flexibility and elasticity over the conventional poly [methyl methacrylate] denture base material. However, most of the studies conducted did not comply with clinically relevant conditions. Thus the present study was conducted to compare and evaluate the most commonly used chair-side soft tissue relining materials, i.e., acrylic based [GC SOFT LINER] and silicone based [MOLLOSIL], when used as functional impression materials, stored in artificial saliva by determining the surface roughness of dental stone over different time periods. Ideally, a material should possess a smooth, polished surface so that plaque accumulation is minimized or avoided. Since a roughened surface attracts plaque, in vivo studies have suggested a "threshold of Ra value" located at a score of $0.2 \mu \mathrm{m}$, below which no further bacterial accumulation can be expected. According to the findings of the present study, no material tested was found to accomplish this criterion, although one exhibited low Ra values ranging from 0.87 to $0.98 \mu \mathrm{m}$, i.e., MOLLOSIL than 0.88 to $1.02 \mu \mathrm{m}$, i.e., GC SOFT LINER.

According to GRAHAM BS et al, in order to avoid deformation of the intaglio surface caused by inadequate elastic recovery of the tissue conditioners, a functional impression should be kept intraorally for atleast 24 hours before pouring the dental stone cast. So it was observed in the present study that the stone samples obtained from the GC SOFT LINER showed less surface roughness changes compared to that of the MOLLOSIL samples, however the surface roughness values were the same for both the soft tissue liner samples after one day of immersion in artificial saliva. Although, it 
was found out that with the increase in duration of the immersion of soft liner samples in artificial saliva, the surface roughness values of both the soft liners increased gradually upto seven days and considerable increase from seven days to twenty one days. However, the percentage increase in the surface roughness of MOLLOSIL samples was considerably lower in comparison to GC SOFT LINER between zero hours to twenty one days. Numerous factors are involved with the surface conditions of soft liners namely saliva, denture cleansing agents, thermocycling, polishing and finishing procedures etc. It is therefore imperative to understand that the changes in surface roughness of the materials used clinically may be different from those obtained from the present study. In 2013, KAMLESHWAR SINGH et al, conducted a study to conclude that the use of a monopoly, a poly [methyl methacrylate] syrup can significantly reduce the loss of softness of a soft liner. However, the effect of varnish on the roughness of soft liners, its compatibility with dental stones and their durability has not been extensively studied. Hence, additional research needs to be performed to produce the ideal soft denture liners which will have both good cushioning effect and better durability.

\section{Conclusion}

The following conclusions were drawn after the comparative study of using two different chair-side soft denture lining materials, as functional impression material, by determining the surface roughness of dental stone over a time period.

A. The stone samples obtained from GC SOFT LINER showed less mean surface roughness value changes compared to MOLLOSIL from upto one day, however, the mean surface roughness values of both the soft tissue liners were the same after one day of immersion in artificial saliva.

B. The mean surface roughness values of both the soft tissue liners increased consistently upto seven days and considerably after seven days.

C. The mean surface roughness values of MOLLOSIL samples increased gradually and consistently over the period of zero hours to twenty days in comparison to the GC SOFT LINER samples, which showed a considerably inconsistent increase.

D. The silicone-based soft liner showed better results for lower surface roughness compared to acrylic-based soft liner, over the period of zero hours to twenty days.

\section{Clinical Implications}

This study suggests that the mean surface roughness of the silicone-based soft liner samples increased consistently, when used as a functional impression material, in relation to the acrylic-based soft liner, over a period of time.

\section{References}

1. Anusavice, Kenneth J (1996) Phillips' science of dental materials. $\left(10^{\text {th }}\right.$ edn), WB Saunders, Philadelphia, USA, pp. 232.
2. Sato Y, Abe Y, Okane H, Tsuga K (2000) Finite element analysis of stress relaxation in soft denture liner. J Oral Rehabil 27(8): 660-663.

3. Kydd WL, Mandley J (1967) The stiffness of palatal mucoperiosteum. J Prosthet Dent 18(2): 116-121.

4. Hayakawa I, Hirano S, Kobayashi S, Nagao M, Masuhara E (1994) The creep behaviour of denture-supporting tissues and soft lining materials. Int J Prosthodont 7(4): 339-347.

5. Anusavice KJ (2004) Phillips' science of dental materials ( $11^{\text {th }}$ edn), WB Saunders, Philadelphia, USA, pp. 721.

6. Juan B Gonzalez, MS William R Laney (1966) Resilient materials for denture prostheses. J Prosthet Dent 16(3): 438-444.

7. Pinto JR, Mesquita MF, Henriques GE, de Arruda Nóbilo MA (2002) Effect of thermocycling on bond strength and elasticity of 4 long-term soft denture liners. J Prosthet Dent 88(5): 516-521.

8. (1991) Dentistry-resilient lining materials for removable denturespart 1: short-term materials. ( $1^{\text {st }}$ edn.), International Organization for Standardization. pp. 10139-10141.

9. (1999) Dentistry-soft lining materials for removable denturespart 2: materials for long-term use. International Organization for Standardization. ISO/FDIS: 10139-10142.

10. Wilson W Chase (1961) Tissue conditioning utilising dynamic adaptive stress. J Prosthet Dent 11(5): 804-815.

11. Pound E (1962) Conditioning of denture patients. J Am Dent Assoc 64: 461-468.

12. Harrison A (1981) Temporary soft lining materials: a review of their uses. Br Dent J 151(12): 419-422.

13. Starche EN, Marcroft KR, Fisher TE, Sweeney WT (1972) Physical properties of tissue conditioning materials as used in functional impression. J Prosthet Dent 27(2): 111-119.

14. Perry W Bascom (1966) Resilient denture base materials. J Prosthet Dent 16(4): 646-649.

15. Hayakawa I, Hirano S, Takahashi Y, Keh ES (2000) Changes in the masticatory function of complete denture wearers after relining the mandibular denture with a soft denture liner. Int J Prosthodont 13(3): 227-231.

16. Polyzois GL, Frangou MJ (2001) Influence of curing method, sealer and water storage on the hardness of a soft lining material over time. J Prosthodont 10(1): 42-45.

17. Bulad K, Taylor RL, Verran J, McCord JF (2004) Colonization and penetration of denture soft lining materials by Candida albicans. Dent Mater 20(2): 167-175.

18. Verran J, Maryan CJ (1997) Retention of Candida albicans on acrylic resin and silicone of different surface topography. J Prosthet Dent 77(5): 535-539.

19. GA Lammie, R Storer (1958) A preliminary report on resilient denture plastics. J Prosthet Dent 8(3): 411-424.

20. JD Eick, RG Craig, FA Peyton (1962) Properties of resilient denture liners in simulated mouth conditions. J Prosthet Dent 12(6): 1043-1052.

21. Tucker KM (1966) Relining complete dentures with the use of a functional impression. J Prosthet Dent 16(6): 1054-1057.

22. John L Sauer (1966) A clinical evaluation of silastic 390 as a lining material for dentures. J Prosthet Dent 16(4): 650-660.

23. Kaiser DA, Nicholls JI (1976) A study of distortion and surface hardness of improved artificial stone casts. J Prosthet Dent 36(4): 373-381.

24. Schmidt WF, Smith DE (1983) A six-year retrospective study of Molloplast-B lined dentures. Part II: Liner serviceability. J Prosthet Dent 50(4): 459-465. 
25. McCarthy JA, Moser JB (1984) Tissue conditioning and functional impression materials and techniques. Dent Clin North Am 28(2): 239251.

26. Khan Z, Morris JC, von Fraunhofer JA (1984) Effect of irreversible hydrocolloid impressions on surface hardness of dental stone. J Prosthet Dent 52(3): 435-437.

27. Gerrow JD, Schneider RL (1987) A comparison of the compatibility of elastomeric impression materials, type IV dental stones, and liquid media. J Prosthet Dent 57(3): 292-298.

28. Kazanji MN, Watkinson AC (1988) Soft lining materials: Their absorption of and solubility in, artificial saliva. Br Dent J 165(3): 91-94.

29. Dootz ER, Koran A, Craig RG (1992) Comparison of the physical properties of 11 soft denture liners. J Prosthet Dent 67(5): 707-712.

30. Dootz ER, Koran A, Craig RG (1993) Physical property comparison of 11 soft denture lining materials as a function of accelerated aging. J Prosthet Dent 69(1): 114-119.

31. Loney WR, Moulding MB (1993) The effect of finishing and polishing on surface roughness of a processed resilient denture liner. Int J Prosthodont 6(4): 390-396.

32. Wright PS (1994) Observations of long-term use of a soft-lining material for mandibular complete dentures, J Prosthet Dent 72(4): 385-392.

33. Kawano F, Dootz ER, Koran A, Craig RG (1994) Sorption and solubility of 12 soft denture liners. J Prosthet Dent 72(4): 393-398.

34. Arima T, Murata H, Hamada T (1995) Properties of highly cross - linked autopolymerising reline acrylic resins. J Prosthet Dent 73(1): 55-59.

35. Wagner WC, Kawano F, Dootz ER, Koran A (1995) Dynamic viscoelastic properties of processed soft denture liners: Part I initial properties. J Prosthet Dent 73(5): 471-477.

36. Wagner WC, Kawano F, Dootz ER, Koran A (1995) Dynamic viscoelastic properties of processed soft denture liners: Part II effect of ageing. J Prosthet Dent 74(3): 299-304.

37. Murata H, McCabe JF, Jepson NJ, Hamada T (1996) The influence of immersion solutions on the viscoelasticity of temporary soft lining materials. Dent Mater 12(1): 19-24.

38. Gronet PM, Driscoll CF, Hondrum SO (1997) Resiliency of surface-sealed temporary soft denture liners. J Prosthet Dent 77(4): 370-374.

39. Reeson MG, Jepson NJ (1998) A simple method for obtaining a uniform thickness for long-term soft denture linings. J Prosthet Dent 79(3): 355357.

40. Zissis AJ, Polyzois GL, Yannikakis SA, Harrison A (2000) Roughness of denture materials: A Comparative Study. Int J Prosthodont 13(2): 136140.

41. Aloul RK, Shen C (2002) The influence of plasticizer loss on the viscoelasticity of temporary soft liners. J Prosthodont 11(4): 254-262.

42. Parr GR, Reuggeberg FA (2002) In vitro hardness, water sorption, and resin solubility of laboratory processed and autopolymerized long-term resilient denture liners over one year of water storage. J Prosthet Dent 88(2): 139-144.

43. Garcia RM, Leon BT, Oliveria VB, Cury AA (2003) Effect of a denture cleanser on weight, surface roughness and tensile bond strength of two resilient denture liners. J Prosthet Dent 89(5): 489-94.

44. Murata H, Hong G, Li YA, Hamada T (2005) Compatibility of tissue conditioners and dental stones: Effect on surface roughness. J Prosthet Dent 93(3): 274-281.
45. León BL, Del Bel Cury AA, Rodrigues Garcia RC (2005) Water sorption, solubility, and tensile bond strength of resilient denture lining materials polymerized by different methods after thermal cycling. J Prosthet Dent 93(3): 282-287

46. Butta R, Tredwin CJ, Nesbit M, Moles DR (2005) Type IV gypsum compatibility with five addition-reaction silicone impression materials. J Prosthet Dent 93(6): 540-544.

47. Bal BT, Yavuzyilmaz H, Yücel M (2008) A pilot study to evaluate the adhesion of oral microorganisms to temporary soft lining materials. J Oral Sci 50(1): 1-8.

48. Machado AL, Breeding LC, Vergani CE, da Cruz Perez LE (2009) Hardness and surface roughness of reline and denture base acrylic resins after repeated disinfection procedures. J Prosthet Dent 102(2):115-122.

49. Gedik H, Ozkan Yk (2009) The effect of surface roughness of siliconebased resilient liner materials on the adherence of Candida albicans and inhibition of Candida albicans with different disinfectants. Oral Health Prev Dent 7(4): 347-353.

50.Vural C, Ozdemir G, Kurtulmus H, Kumbuloglu O, Ozcan M (2010) Comparative effects of two different artificial body fluids on Candida albicans adhesion to soft lining materials. Dent Mater J 29(2): 206-212.

51. Kang SH, Lee HJ, Hong SH, Kim KH, Kwon TY (2013) Influence of surface characteristics on the adhesion of Candida albicans to various denture lining materials. Acta Odontol Scand 71(1): 241-248.

52. Singh K, Tripathi A, Chand P, Mishra N, Agrawal KK, et al. (2013) A study to evaluate the effect of monopoly on the softness of soft liner by durometer. Indian Journal of dentistry 4: 137-140.

53. Hadary AE, Drummond JL (2000) Comparative study of water sorption, solubility, tensile bond strength of two soft lining materials. J Prosthet Dent 83(3): 356-361.

54. Jin C, Nikawa H, Makihira S, Hamada T, Furukawa M, et al. (2003) Changes in surface roughness and colour stability of soft denture lining materials caused by denture cleansers. J Oral Rehabil 30(2): 125-130.

55. Wright PS (1984) The success and failure of denture soft lining materials in clinical use. J Dent 12(4): 319-327.

56. Anusavice KJ (2004) Phillip's science of dental materials $\left(11^{\text {th }}\right.$ edn) Saunders: St Louis, Missouri, USA, pp. 721,750-751.

57. 0 Brien WG (1997) Dental materials and their selection. ( $2^{\text {nd }}$ edn) Quintessence publication, North Kimberly, USA, p. 90-95.

58. Goll G Smith DE, Plein JB (1983) The effect of denture cleansers on temporary soft liners. J Prosthet Dent 50(4): 466-472.

59. Graham BS, Jones DW, Sutow EJ (1989) Clinical implications of resilient denture lining material research. Part I: Flexibility and elasticity. J Prosthet Dent. 62(4): 421-428.

60. Vig RG (1964) A modified chew-in and functional impression technique. J Prosthet Dent 14: 214-220.

61. Nikawa H, Yamamoto T, Hayashi S, Nikawa Y, Hamada T (1994) Growth and/or acid production of Candida albicans on soft lining materials in vitro. J Oral Rehabil 21(5): 585-594.

62. Nikawa H, Hamada T, Yamamoto T (1998) Denture plaque past and recent concerns. J Dent 26(4): 299-304. 


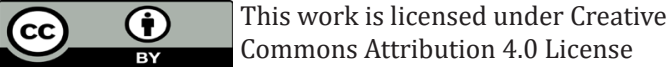

To Submit Your Article Click Here: Submit Article

DOI: 10.32474/MADOHC.2018.03.000159

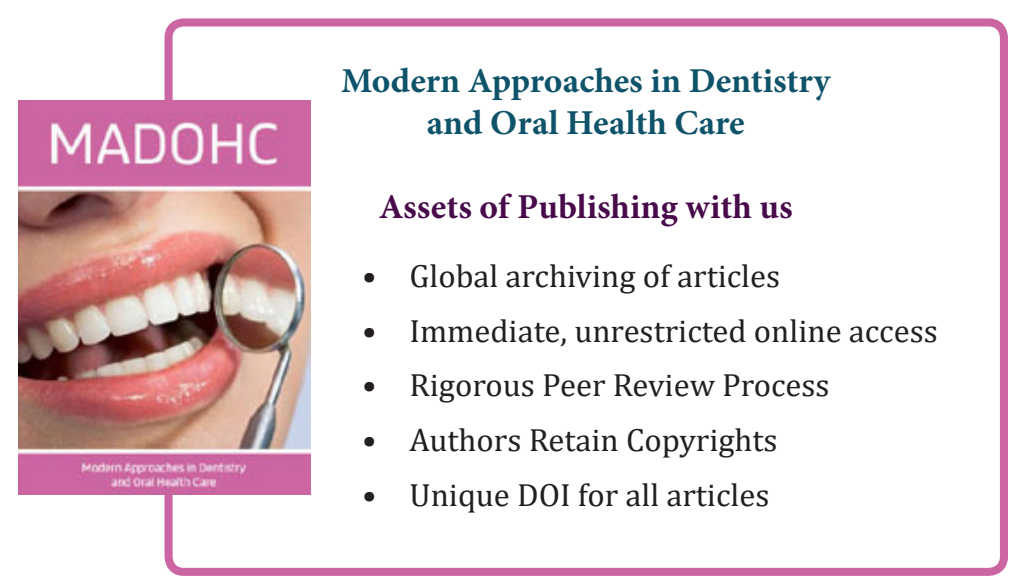

